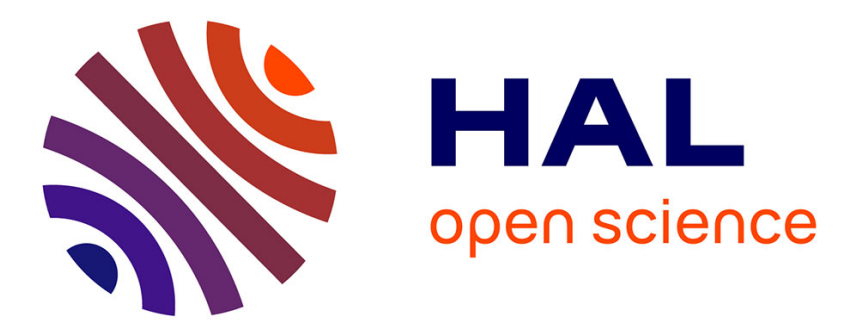

\title{
Chemoenzymatic synthesis of L-tyrosine derivative for a transketolase assay
}

Franck Charmantray, Virgil Hélaine, Angelika Lasikova, Bertrand Legeret, Laurence Hecquet

\section{> To cite this version:}

Franck Charmantray, Virgil Hélaine, Angelika Lasikova, Bertrand Legeret, Laurence Hecquet. Chemoenzymatic synthesis of L-tyrosine derivative for a transketolase assay. Tetrahedron Letters, 2008, 49, pp.3229-3233. hal-00275587

\section{HAL Id: hal-00275587 \\ https://hal.science/hal-00275587}

Submitted on 24 Apr 2008

HAL is a multi-disciplinary open access archive for the deposit and dissemination of scientific research documents, whether they are published or not. The documents may come from teaching and research institutions in France or abroad, or from public or private research centers.
L'archive ouverte pluridisciplinaire HAL, est destinée au dépôt et à la diffusion de documents scientifiques de niveau recherche, publiés ou non, émanant des établissements d'enseignement et de recherche français ou étrangers, des laboratoires publics ou privés. 


\title{
Chemoenzymatic synthesis of L-tyrosine derivative for a transketolase assay
}

\author{
Franck Charmantray $^{\mathrm{a}}$, Virgil Hélaine ${ }^{\mathrm{a}}$, Angelika Làsikovà ${ }^{\mathrm{b}}$, Bertrand Legeret ${ }^{\mathrm{a}}$, \\ Laurence Hecquet ${ }^{\mathrm{a}, *}$
}

${ }^{a}$ Université Blaise Pascal, Laboratoire de Synthèse et Etude de Systèmes à Intérêt Biologique, UMR CNRS 6504, 63177 Aubière Cedex, France

${ }^{\mathrm{b}}$ Slovak University of Technology, Department of Organic Chemistry, Radlinskeo 9, 81237 Bratislava, Slovak Republic

\begin{abstract}
We have prepared an L-tyrosine derivative bearing a D-threo ketose moiety by a convenient chemoenzymatic route. This compound is of potential interest for developing stereospecific assays for enzymes catalyzing $\mathrm{C}-\mathrm{C}$ bond cleavage such as transketolase. We showed in vitro by analytical studies (LC/MS and ${ }^{31} \mathrm{P}$ NMR) that this compound can release L-tyrosine in the presence of wild type TK extract and bovine serum albumin. This assay is the first step towards a mutant TK selection test that could be developed for yeast cells auxotrophic for L-tyrosine.
\end{abstract}

Keywords: Biocatalysis; Tyrosine; Transketolase; Assay

Transketolase is a useful catalyst for ketose synthesis through the stereocontrolled formation of the $\mathrm{C}_{2}-\mathrm{C}_{3}$ bond (Scheme 1). TK isolated from spinach leaves, ${ }^{1}$ baker's yeast, $^{2}$ Escherichia coli ${ }^{3}$ and Saccharomyces cerevisiae recombinant $\mathrm{TK}^{4}$ has been used for synthetic purposes. ${ }^{5}$ TK reaction is reversible except when the donor substrate is $\beta$-hydroxypyruvic acid. This property is very convenient for synthetic purposes because the decarboxylation of this donor substrate makes the overall condensation reaction irreversible. TK catalyses the transfer of a ketol unit from $\beta$-hydroxypyruvic acid to an aldehyde to give a D-threo
$(3 S, 4 R)$ ketose. TK is very specific for ketol as donors and for hydroxyaldehydes in the $(R)$ configuration as acceptors. In the course of generating yeast TK with new or improved substrate specificities, an efficient screening or selection system is an absolute prerequisite for identifying evolved enzyme variants that display improved properties. Only screening tests have been developed for this type of enzyme. Various assays for TK activity determination have been proposed using detection by spectrophotometry with NADH-dependent enzymes. ${ }^{6}$ More recently, a colorimetric assay was reported in the presence of tetrazolium

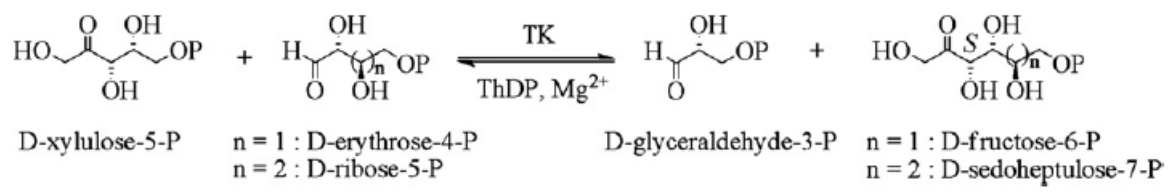

Scheme 1 .

\footnotetext{
* Corresponding author. Tel.: +33473 407871; fax: +33 473407717 .

E-mail address: Laurence.HECQUET@univ-bpclermont.fr (L. Hecquet).
} 


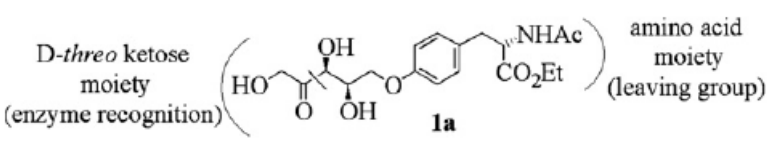

Scheme 2.

red. ${ }^{7}$ To detect modifications of the stereospecificity of mutant TK, we have developed a fluorogenic screening test for TK based on the detection of coumarine from stereochemical probes. ${ }^{8}$ However, these in vitro assays have a major disadvantage. For screening large libraries of mutant enzymes, it is necessary to disrupt each clone separately to determine the catalytic properties of the mutant enzyme, unlike for selection tests. As a rule, these latter efficiently combine the enzymatic catalytic activity with a survival factor, a growth advantage for the micro-organisms. In this context, we target fused molecules containing a sugar moiety with varied stereochemistries for mutant TK recognition and an aminoacid as a possible leaving group for cell supply.

First, we sought to validate the principle of the assay in vitro with wild-type TK extract and compound 1 bearing a D-threo ketose moiety and L-tyrosine as the leaving group (Scheme 2).

Here we report on the synthesis of compound 1a by a straightforward chemoenzymatic route, avoiding protection and deprotection steps, as previously described for obtaining a D-threo ketose analogue bearing umbelliferone instead of tyrosine moiety, by a chemical route. ${ }^{9}$ The assay was studied in vitro with TK extract from yeast. We used LC/MS and ${ }^{31} \mathrm{P}$ NMR experiments to monitor both the first step catalyzed by wild-type TK reaction from 1 and the second step in which the protected L-tyrosine was released on BSA catalyzed $\beta$-elimination.

We developed a chemoenzymatic strategy in which both chiral centres $(3 S, 4 R)$ of compound 1 sugar moiety were introduced together by $\mathrm{C}-\mathrm{C}$ bond formation in a highly stereoselective manner, catalyzed by fructose-1,6-bisphosphate aldolase from rabbit muscle, RAMA (E.C. 4.1.2.13), in the presence of dihydroxyacetonephosphate (DHAP) as donor substrate and the suitable aldehyde $\mathbf{2}$ as acceptor (Scheme 3). This step was followed by dephosphorylation of the aldol product catalyzed by acid phosphatase (E.C. 3.1.3.2) at $\mathrm{pH}$ 4.7. This strategy is most often used to produce $(3 S, 4 R)$ ketoses such as ${ }^{13} \mathrm{C}$ labelled sugars, heteroatom-substituted sugars, deoxy sugars, fluoro sugars, long-chain sugars and cyclitols. Well over 100 aldehydes have been described as acceptor substrates. ${ }^{10}$
In our case, the appropriate acceptor aldehyde for the aldol condensation catalyzed by RAMA in the presence of DHAP was compound 2. To our knowledge, this was the first time a C-2 amino acid substituted aldehyde was a substrate of RAMA. The aldehyde was made by ozonolysis of the double bond of compound 3. Carboxylic acid was protected as ethyl ester and amine by usual protecting groups: $\mathrm{Cbz}$, Boc, acetyl or trifluoroacetyl.

Compounds 4 were either commercially available (4a) or synthesized from L-tyrosine ethylester $\left(\mathbf{4 b}, 91 \% ;{ }^{11} \mathbf{4 c}\right.$, $\left.83 \% ;{ }^{12} \mathbf{4 d}, 91 \%{ }^{13}\right)$. Compounds 4a-d were first allylated in refluxing acetone to give the corresponding intermediates $\left(3 \mathbf{a}, 91 \%{ }^{14} \mathbf{3 b}, 62 \% ; \mathbf{3 c}, 91 \%\right.$; 3d, 90\%). Subsequent ozonolysis of the crude products in methylene chloride at $-78^{\circ} \mathrm{C}$ followed by the reduction of the ozonides with dimethyl sulfide gave the aldehydes (2a, 74\%; 2 b, 62\%; 2c, $32 \% ; 2 d, 22 \%$ ).

Aldehydes $\mathbf{2 c}$ and $\mathbf{2 d}$ in the presence of RAMA did not react with DHAP, as shown by enzymatic assay. ${ }^{15}$ This might be due to the marked hydrophobic character, along with steric hindrance, of the $\mathrm{Cbz}$ and Boc amino protecting groups.

Adding co-solvents such as $10 \%$ DMSO, DMF or methanol did not improve the results.

By contrast, aldehydes $\mathbf{2 a}$ and $\mathbf{2 b}$ underwent efficient aldol addition with DHAP owing to lower steric hindrance and better solubility with $10 \%$ methanol.

Crude compounds 1a and 1b were obtained after dephosphorylation catalyzed by acid phosphatase (E.C. 3.1.3.2). NMR analysis of the crude enzymatic mixtures showed that compound 1a was the main product $(89 \%$ according to ${ }^{1} \mathrm{H}$ NMR in the presence of TMSP- $d_{4}$ as calibrate). Compound $\mathbf{1 b}$ was a minor product owing to the ester and (or) trifluoroacetyl protecting group hydrolysis. So we focused our strategy on compound 1a. A pure analytical amount of 1a, necessary for in vitro studies, was obtained after purification by reverse-phase semi-preparative LC. This is the first time an amino acid branched sugar has been generated using RAMA as a catalyst, thus extending its scope for syntheses.

The enzymatic assay was based on TK-catalyzed $\mathrm{C}_{2}-\mathrm{C}_{3}$ bond cleavage from donor substrates 1a and subsequent transfer of the hydroxyacetyl group released to D-ribose5 -phosphate, the natural acceptor substrate of TK (Scheme $4)$. This reaction led to the formation of D-sedoheptulose-7phosphate along with the $\alpha$-hydroxyaldehyde $1 \mathbf{a}^{\prime}$. According to the literature ${ }^{16}$ and our own results with coumarine in place of L-tyrosine, the $\beta$-elimination reaction from $1 \mathbf{a}^{\prime}$

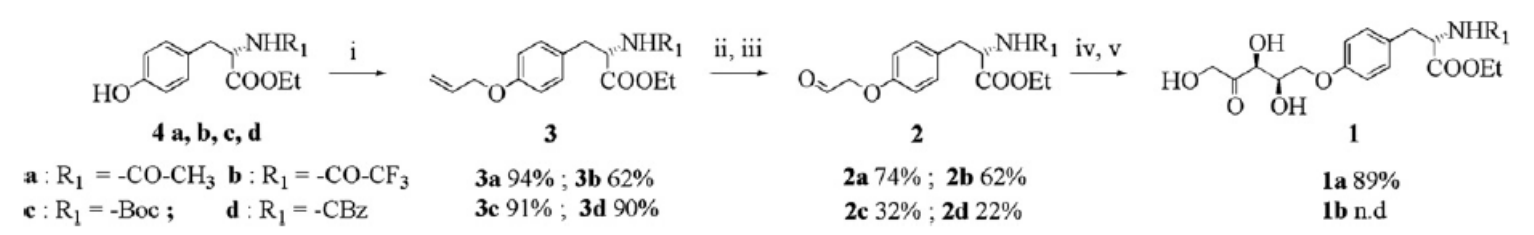

Scheme 3. Reagents and conditions: (i) $\mathrm{K}_{2} \mathrm{CO}_{3}$, allylbromide; (ii) $\mathrm{O}_{3}$; (iii) DMS; (iv) DHAP, RAMA, pH 7.5; (v) acid phosphatase pH 4.7 . 


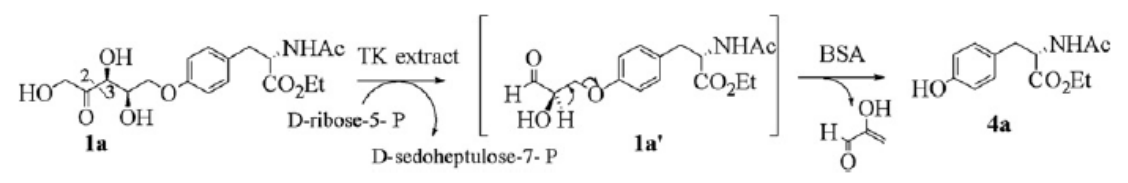

Scheme 4 .

analogues takes place satisfactorily using bovine serum albumin (BSA). Under these conditions, the intermediate $1 \mathbf{a}^{\prime}$ led to the release of protected L-tyrosine 4a. We carried out ${ }^{31} \mathrm{P}$ NMR and LC/MS experiments to monitor these two reactions in comparison with the control, that is, intrinsic chemical stability of compound 1a under the same conditions. Our aim was to show qualitatively that TK extract and BSA specifically catalyzed the release of $1 \mathbf{a}^{\prime}$ and $4 \mathrm{a}$ respectively.

${ }^{31} \mathrm{P}$ NMR was suitable for following the conversion of D-ribose-5-phosphate into D-sedoheptulose-7-phosphate in the first step of the assay. Reaction progress was followed by recording ${ }^{31} \mathrm{P}$ NMR spectra decoupled from ${ }^{1} \mathrm{H}$ and ${ }^{13} \mathrm{C}$ and using $\mathrm{H}_{3} \mathrm{PO}_{4}$ as internal standard for the calibration. We showed the stability of both phosphorylated monosaccharides with TK at pH 7.2 in Mops buffer and without the donor substrate 1a.

In the presence of 1a, the conversion of D-ribose-5-phosphate to D-sedoheptulose-7-phosphate occurred, as shown by the disappearance of the signal of D-ribose-5-phosphate at $3.5 \mathrm{ppm}$ and the appearance of the signal of D-sedoheptulose-7-phosphate at $4.35 \mathrm{ppm}$ at the same time.

The ${ }^{31} \mathrm{P}$ NMR shift of D-sedoheptulose-7-phosphate matched that obtained from an authentic sample prepared according to a procedure described in the literature. ${ }^{17}$ This study demonstrated that TK catalyzed the hydroxyacetyl group transfer from the donor substrate 1a to D-ribose-5phosphate, the natural acceptor substrate of TK.

The experiments were carried out at pH 7.2 (Mops buffer) and $\mathrm{pH} 8.2$ (Bicine buffer) to compare the influence of the $\mathrm{pH}$ on the reaction rates. These $\mathrm{pH}$ values were close to the common values used for the TK reaction and for $\beta$ elimination catalyzed by BSA. ${ }^{18}$

First, we studied the step catalyzed by TK. We showed that compound 1a was stable at both $\mathrm{pH} 7.2$ and 8.2, in the presence of TK extract (Fig. 1). When the acceptor substrate, D-ribose-5-phosphate was added to the reaction mixture containing compound 1a and TK extract, we followed the disappearance of 1a (retention time: $11.3 \mathrm{~min}$; HRMS m/z: $\left[\mathrm{M}+\mathrm{Na}^{+}\right]$: calculated for $\mathrm{C}_{18} \mathrm{H}_{25} \mathrm{NO}_{8} \mathrm{Na}$ 406.1478, found 406.1472) and at the same time the appearance of compound $1 \mathbf{a}^{\prime}$. This compound was characterized by its exact mass (retention time: $8.5 \mathrm{~min}$; C18 XTerra ${ }^{\circledR}$ $2.1 \mathrm{~mm} \times 100 \mathrm{~mm}$, Waters. Reaction products were successively eluted along the elution gradient water/acetonitrile/ formic acid 94.9/5/0.1, v/v/v to water/acetonitrile/formic acid 5/94.9/0.1 v/v/v. HRMS $m / z$ : $\left[\mathrm{M}+\mathrm{Na}^{+}\right]$: calculated for $\mathrm{C}_{16} \mathrm{H}_{21} \mathrm{NO}_{6} \mathrm{Na}$ : 346.1267 , found: 346.1262 ). We noted that the TK-catalyzed reaction was not $\mathrm{pH}$-dependent. Hence we showed that TK catalyzed $\mathrm{C}_{2}-\mathrm{C}_{3}$ bond cleavage

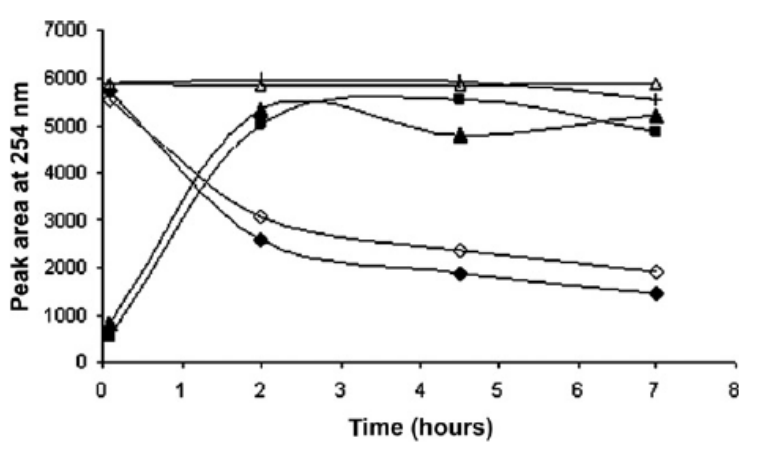

Fig. 1. Release of compound $1 \mathbf{a}^{\prime}$ from la catalyzed by TK. Controls: 1a $(100 \mu \mathrm{M})$, TK extract ( 1 unit $\left.\mathrm{mL}^{-1}\right) ; \triangle$ : $1 \mathrm{a}$ in Bicine buffer $\mathrm{pH} 8.2 ;+$ : 1a in Mops buffer pH 7.2. Reactions: 1a $(100 \mu \mathrm{M})$, D-ribose-5-phosphate $(100 \mu \mathrm{M})$, TK extract $\left(1\right.$ unit $\left.\mathrm{mL}^{-1}\right) ; \diamond: \mathbf{1 a}, \mathbf{\Delta}: \mathbf{1} \mathbf{a}^{\prime}$ in Bicine buffer $0.1 \mathrm{M}$ pH $8.2 ;: \mathbf{1 a}, \mathbf{\square}: \mathbf{1 a}^{\prime}$ in Mops buffer $0.1 \mathrm{M}$ pH 7.2 .

from compound 1a, confirming the results obtained previously using ${ }^{31} \mathrm{P}$ NMR.

Second, we set out to show that BSA catalyzed the $\beta$ elimination from 1a to protected L-tyrosine 4a (retention time: $14.5 \mathrm{~min}$; HRMS $\mathrm{m} / \mathrm{z}$ : $\left[\mathrm{M}+\mathrm{Na}^{+}\right]$: calculated for $\mathrm{C}_{13} \mathrm{H}_{17} \mathrm{NO}_{4} \mathrm{Na} 274.1055$, found 274.1049). First of all, we checked the stability of compound 1a in the presence of BSA. Figure 2 shows that compound 1a slightly decomposed to $4 \mathrm{a}$, the rate being twice as high in Bicine buffer as in Mops buffer. This background noise could be due to BSA, as already mentioned on an analogue fluorogenic compound, ${ }^{8 \mathrm{a}}$ or to a non-enzymatic hydroxyacetyl group transfer as recently described by Hailes and co-workers. ${ }^{19}$ When TK and D-ribose-5-phosphate were added, $\mathrm{N}$ acetyl-L-tyrosine ethyl ester $\mathbf{4 a}$ was released at a rate 10 times higher in Mops and 5 times higher in Bicine than

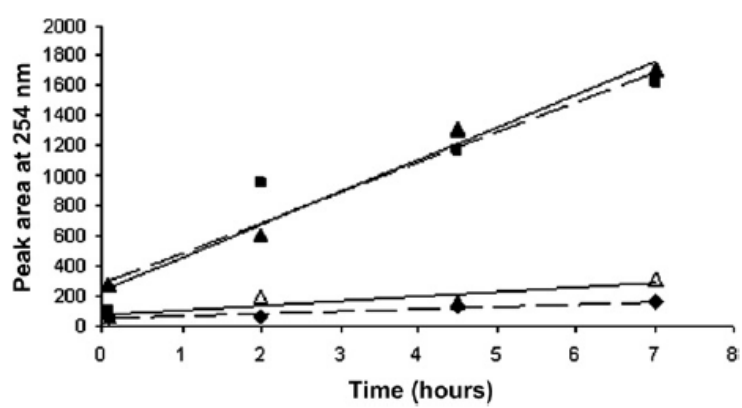

Fig. 2. Release of 4a from 1a catalyzed by TK and BSA. Controls: 1a $(100 \mu \mathrm{M})$, BSA $\left(2 \mathrm{mg} \mathrm{mL}^{-1}\right) ; \triangle: 1 \mathrm{a}$ in Bicine buffer $0.1 \mathrm{M} \mathrm{pH} 8.2, \downarrow: 1 \mathrm{a}$ in Mops buffer $0.1 \mathrm{M}$ pH 7.2. Reactions: 1a $(100 \mu \mathrm{M})$, BSA $\left(2 \mathrm{mg} \mathrm{mL}^{-1}\right)$, D-ribose-5-phosphate $(100 \mu \mathrm{M})$, TK extract ( 1 unit $\left.\mathrm{mL}^{-1}\right) ; \mathbf{\Delta}: 4 \mathrm{a}$ in Bicine buffer $0.1 \mathrm{M}$ pH 8.2, $\mathbf{\square}$ : $\mathbf{4 a}$ in Mops buffer $0.1 \mathrm{M} \mathrm{pH} \mathrm{7.2.}$ 
previously. The absolute rates of compound 4a release were similar in any buffer. Consistent with the difference in the stability of compound 1a in each buffer, the relative rate of compound 4a release in Mops buffer was twice as high as in Bicine buffer. Hence, Mops buffer (pH 7.2) is more suitable than Bicine buffer ( $\mathrm{pH} 8.2$ ).

LC/MS monitoring enabled us to confirm the efficiency of the TK-catalyzed first step by identifying $\alpha$-hydroxyaldehyde key intermediate $1 \mathbf{a}^{\prime}$, and the efficiency of the BSAcatalyzed second step by identifying protected L-tyrosine 4a released.

As the ultimate aim could be to develop this TK selection assay in vivo in yeast cells, the deprotection of 4 a by an enzymatic route can be investigated. Usually, the enzymes commonly used for hydrolysing an ester and an acetyl group are proteases and acylases, respectively, as described for other similarly protected amino acids. ${ }^{11,20}$ Using commercially available hydrolases, subtilisin and acylase I, compound 4a was fully converted sequentially into L-acetyltyrosine and then tyrosine.

In conclusion, we synthesized compound 1a in four steps from protected L-tyrosine 4a. From compound 1a we performed an enzymatic assay leading, in two steps, to the release of protected L-tyrosine. We showed by analytical studies that in the first step, compound 1a was a donor substrate for TK in the presence of D-ribose-5-phosphate as acceptor substrate. To our knowledge, only compounds such as the natural substrate D-xylulose-5-phosphate, $\beta$ hydroxypyruvic acid or L-erythrulose, have been considered as possible donor substrates for TK. Both our previous $^{8}$ and current work show that the substrate specificity of TK for the donor substrate is broader than expected.

We demonstrated the possibility of detecting wild type TK activity in vitro from compound 1a based on the release of L-tyrosine. In the future, and to make this test usable in vivo, a prerequisite will be the limitation of the background signal for the direct cleavage of 1a into $\mathbf{4 a}$. For cells both auxotrophic for L-tyrosine and expressing TK, it should be possible to carry out this assay in vivo. This strategy could offer the first stereospecific selection test for TK mutants.

Preparation of $\mathrm{N}$-acetyl- $\mathrm{O}^{\prime}-(2 \mathrm{R}, 3 \mathrm{~S}, 5$-trihydroxy-4-oxopentyl)-L-tyrosine ethyl ester (1a): $N$-Acetyl- $O^{\prime}$-(2-oxoethyl)-L-tyrosine ethyl ester 2a $(1.1 \mathrm{~g}, 3.75 \mathrm{mmol})$ was dissolved in water/methanol, 1/1, v/v. After dissolution, $7 \mathrm{ml}$ of water were added dropwise. Dihydroxyacetone phosphate ( $360 \mathrm{mM}, 3.75 \mathrm{mmol}, 1$ equiv, $\mathrm{pH} 7)$ was added thereafter (to give a $200 \mathrm{mM}$ final substrate concentration) followed by 385 units of RAMA. The mixture was stirred for 24 hours at room temperature; the reaction was followed by ${ }^{13} \mathrm{C}$ NMR in $\mathrm{H}_{2} \mathrm{O} / \mathrm{D}_{2} \mathrm{O}, 9 / 1$, v/v; until complete disappearance of the starting aldehyde. The $\mathrm{pH}$ was adjusted to 4.8 and 370 units of acid phosphatase were added. The mixture was then stirred overnight. 3 volumes of methanol were added. The precipitate was discarded by centrifugation at $8000 \mathrm{rpm}$ and the subsequent superna- tant was evaporated to dryness under vacuum. $[\alpha] 5.78(c$ 1.2, MeOH) Yield: $89 \%$ according the ${ }^{1} \mathrm{H}$ NMR. ${ }^{1} \mathrm{H}$ NMR $\left(\mathrm{CD}_{3}\right)_{2} \mathrm{CO} \delta(\mathrm{ppm}): 1.10\left(\mathrm{t}, 3 \mathrm{H}, J=7 \mathrm{~Hz}, \mathrm{CH}_{3}\right.$ ester); $1.82\left(\mathrm{~s}, 3 \mathrm{H}, \mathrm{CH}_{3}\right.$ acetyl); $2.78(\mathrm{dd}, 1 \mathrm{H}, J=9$, $14 \mathrm{~Hz}, \mathrm{CH}$ part of $\left.\mathrm{CH}_{2}-\mathrm{Ar}\right) ; 2.94(\mathrm{dd}, 1 \mathrm{H}, J=6,14 \mathrm{~Hz}$, $\mathrm{CH}$ part of $\mathrm{CH}_{2}-\mathrm{Ar}$ ); 3.89 (dd, $1 \mathrm{H}, J=6,9 \mathrm{~Hz}, \mathrm{CH}$ part of $\left.\mathrm{CH}_{2} \mathrm{O}\right) ; 3.99\left(\mathrm{dd}, 1 \mathrm{H}, J=6,9 \mathrm{~Hz}, \mathrm{CH}\right.$ part of $\mathrm{CH}_{2-}$ O); 4.02 (q, 2H, $J=7 \mathrm{~Hz}, \mathrm{CH}_{2}$ ester); 4.17-4.21 (m, 1H, $\mathrm{CH}-\mathrm{OH}) ; 4.28(\mathrm{~d}, 1 \mathrm{H}, J=2 \mathrm{~Hz}, \mathrm{CH}-\mathrm{OH}) ; 4.39$ (d, $1 \mathrm{H}$, $J=20 \mathrm{~Hz}, \mathrm{CH}$ part of $\left.\mathrm{CH}_{2}-\mathrm{OH}\right) ; 4.43(\mathrm{~d}, 1 \mathrm{H}, J=20 \mathrm{~Hz}$, $\mathrm{CH}$ part of $\left.\mathrm{CH}_{2}-\mathrm{OH}\right) ; 4.50(\mathrm{dd}, 1 \mathrm{H}, J=6,9 \mathrm{~Hz}, \mathrm{CH})$; $6.76(\mathrm{~d}, 2 \mathrm{H}, J=9 \mathrm{~Hz}, \mathrm{CHAr}) ; 7.01(\mathrm{~d}, 2 \mathrm{H}, J=9 \mathrm{~Hz}$, CHAr); ${ }^{13} \mathrm{C}$ NMR $\left(\mathrm{CD}_{3}\right)_{2} \mathrm{CO} \delta$ (ppm): $14.5\left(\mathrm{CH}_{3}\right) ; 22.3$ $\left(\mathrm{CH}_{3}\right) ; 37.7\left(\mathrm{CH}_{2}\right) ; 55.6(\mathrm{CH}) ; 62.3\left(\mathrm{CH}_{2}\right) ; 68.0\left(\mathrm{CH}_{2}\right)$; $71.8\left(\mathrm{CH}_{2}\right) ; 72.5(\mathrm{CH}) ; 77.0(\mathrm{CH}) ; 115.6(2 \mathrm{CHAr}) ; 130.5$ (CAr); 131.3 (2CHAr); 159.1 (CAr); 169.9 (C=O ester); $173.2(\mathrm{C}=\mathrm{O}$ amide $) ; 212.4(\mathrm{C}=\mathrm{O}$ ketone); HRMS $\mathrm{m} / \mathrm{z}$ : $\left[\mathrm{M}+\mathrm{Na}^{+}\right]$: calculated for $\mathrm{C}_{18} \mathrm{H}_{25} \mathrm{NO}_{8} \mathrm{Na} 406.1478$, found 406.1472. A sample of compound 1a was further purified by HPLC using C18 XTerra ${ }^{\circledR}$ column (Waters), $7.6 \mathrm{~mm} \times 100 \mathrm{~mm}$ Isocratic solvent system water/acetonitrile; $89 / 11$, v/v, was used to elute 1 a at $4.2 \mathrm{~mL} \mathrm{~min}^{-1}$. In those conditions 1a was recovered in $4 \mathrm{mg}$ scale as pure compound according to LC/MS analysis performed on an analytical XTerra C18 column; $2.1 \mathrm{~mm} \times 100 \mathrm{~mm}$ (Waters). ${ }^{21}$

\section{Acknowledgements}

We thank MENRT for its financial support (postdoctoral fellowship for Dr. A.L.). We thank Professor G. Schneider (Karolinska Institut, Division of Molecular Biology, S-17177 Stockholm, Sweden) for the gift of the yeast strain H402 transformed with pTKL1.

\section{Supplementary data}

Supplementary data associated with this article can be found, in the online version, at doi:10.1016/j.tetlet. 2008.03.099.

\section{References and notes}

1. Bolte, J.; Demuynck, C.; Hecquet, L.; Samaki, H. Carbohydr. Res. 1990, 206, 79-85.

2. (a) Ziegler, T.; Straub, A.; Effenberger, F. Angew. Chem., Int. Ed. Engl. 1988, 27, 716-721; (b) Kobori, Y.; Myles, D. C.; Withesides, G. M. J. Org. Chem. 1991, 22, 5899-5907.

3. (a) Morris, K. G.; Smith, M. E. B.; Turner, N. J. Tetrahedron: Asymmetry 1996, 7, 2185-2188; (b) Zimmermann, F. T.; Schneider, A.; Schörken, Y.; Sprenger, G. A.; Fessner, W. D. Tetrahedron: Asymmetry 1999, 10, 1643-1646.

4. (a) Wikner, C.; Meshalkina, L.; Nilsson, U.; Nikkola, M.; Lindqvist, Y.; Schneider, G. J. Biol. Chem. 1994, 269, 32144-32150; (b) Nilsson, U.; Hecquet, L.; Gefflaut, T.; Guérard, C.; Schneider, G. FEBS Lett. 1998, 424, 49-52.

5. (a) André, C.; Guérard, C.; Hecquet, L.; Demuynck, C.; Bolte, J. J. Mol. Catal. B: Enzym. 1998, 5, 459-466; (b) Guérard, C.; Alphand, V.; Archelas, A.; Demuynck, C.; Hecquet, L.; Furstoss, R.; Bolte, J. 
Eur. J. Org. Chem. 1999, 1, 3399-3402; (c) Crestia, D.; Guérard, C. Veschambre, H.; Hecquet, L.; Demuynck, C.; Bolte, J. Tetrahedron: Asymmetry 2001, 12, 869-876.

6. (a) Horecker, B. L.; Smyrniotis, P. Z. Methods Enzymol. 1955, 1, 371375; (b) Hecquet, L.; Bolte, J.; Demuynck, C. Biosc. Biotech. Biochem. 1993, 12, 2174-2176; (c) Sevostyanova, I. A.; Solovjeva, O. N.; Kochetov, G. A. Biochemistry (Mosc). 2006, 71, 560-562.

7. Smith, M. E. B.; Kaulmann, U.; Ward, J. M.; Hailes, H. C. Bioorg Med. Chem. 2006, 14, 7062-7065.

8. (a) Sevestre, A.; Hélaine, V.; Guyot, G.; Martin, C.; Hecquet, L. Tetrahedron Lett. 2003, 44, 827-830; (b) Sevestre, A.; Charmantray, F.; Hélaine, V.; Lasikova, A.; Hecquet, L. Tetrahedron 2006, 62, 3969-3976.

9. Gonzalez-Garcia, E.; Hélaine, V.; Klein, G.; Schuermann, M.; Sprenger, G. A.; Fessner, W. D.; Reymond, J. L. Chem. Eur. J. 2003, 9, 893-899.

10. Machajewski, T. D.; Wong, C.-H. Angew. Chem., Int. Ed. 2000, 39, 1352-1374.

11. Bois-Choussy, M.; Zhu, J. J. Org. Chem. 1998, 63, 5662-5665.

12. Hioki, K.; Kinugasa, M.; Kishimoto, M.; Fujiwara, M.; Tani, S.; Kunishima, M. Synthesis 2006, 12, 1931-1933.
13. Delle Monache, G.; Di Giovanni, M. C.; Maggio, F.; Misiti, D.; Zappia, G. Synthesis 1995, 9, 1155-1158.

14. Tous, G.; Bush, A.; Tous, A.; Jordan, F. J. Med. Chem. 1990, 33, $1620-1634$.

15. Bergmeyer, H. U. Methods in Enzymatic Analysis, 34th ed.; Chemie, 1984; pp 146-147.

16. (a) Klein, G.; Reymond, J. L. Helv. Chim. Acta 1999, 82, 400-407; (b) Badalassi, F.; Wahler, D.; Klein, G.; Crotti, P.; Reymond, J. L. Angew. Chem., Int. Ed. 2000, 39, 4067-4070; (c) Perez-Carlon, R.; Jourdain, N.; Reymond, J. L. Chem. Eur. J. 2000, 6, 41544162.

17. Lee, S.; Kirschning, A.; Müller, M.; Way, C.; Floss, H. G. J. Mol Catal. B 1999, 6, 369-377.

18. Klein, G.; Reymond, J. L. Bioorg. Med. Chem. Lett. 1998, 8, 11131116.

19. Smith, M. E. B.; Smithies, K.; Senussi, T.; Dalby, P.; Hailes, H. C. Eur. J. Org. Chem. 2006, 5, 1121-1123.

20. Easton, C. J.; Harper, J. B. Tetrahedron Lett. 1998, 39, 5269-5272.

21. Linear gradient elution was used from water/acetonitrile/formic acid, 94.9/5/0.1, v/v/v to water/acetonitrile/formic acid 5/94.9/0.1, $\mathrm{v} / \mathrm{v} / \mathrm{v}$. 